\title{
APSKATI
}

DOI: http://doi.org/10.22364/adz.54.12

\section{TĒZES 95 DIENĀS}

Ilze Stikāne, projekta Reformācija šodien jeb 95 jaunas tēzes vadītāja

Īstenojot Latvijas Universitātes Teolog̣ijas fakultātes (LU TF) akadēmiskās attīstības projektu Reformācija šodien jeb 95 jaunas tèzes, tika izveidota Facebook lapa 95 tēzes 95 dienās, kurā ik dienu tika publicēta viena Dr. Mārtina Lutera tēze un tās mūsdien̄̄ga interpretācija, ko piedāvāja dažāau jomu, profesiju un pārliecību pārstāvji. Tēzes interpretēja mācitāji, mūziḳi, mākslinieki, politiḳi, profesori, skolotāji, mērnieki, arhitekti, dzejnieki, rakstnieki, fotogrāfi, vēsturnieki, restauratori, žurnālisti, kā arī daudzi citi. LU TF docents Juris Cālīitis ir norādījis, ka ar šo projektu ir îstenots svarīgs teologísks konteksts, proti - ka visi cilvēki ir teologi. Svarīgi arī uzsvêrt, ka šī ir pirmā reize, kad Latvijā ar tik dažāāām pieejām ir interpretētas M. Lutera tēzes, tādējādi pārrakstot tās 21. gadsimta kontekstā.

Projekts bija veltīts M. Lutera 95 tēžu 500 gadu jubilejai. Tā ietvaros tika veidots arī diskusiju cikls (Prāts ar/vai/pret ticību; Vai mūsdienās var nejaušsi sākt reformāciju?; Baznīcas atbildība šodien: vai Baznīca atbild cilvēku vai Dieva priekšāa?; 95 jaunas tēzes?), kurā tika apskatîti M. Lutera ieskati gan valsts un Baznīcas, gan sabiedrïbas un cilvēka līmenī.

Facebook lapas 95 tēzes 95 dienās veidošanas laikā tika uzrunāti vairāk nekā 215 cilvēku, lai vini piedalītos projektā ar savu tēžu interpretāciju. Facebook lapā Lutera tēzes un to mūsdienīgas interpretācijas tika publicētas no 2017. gada 31. oktobra līdz pat 2018. gada 2. februārim. Lapai projekta noslēgumā bija vairāk nekā 440 sekotāju. Visas tē̌̌u interpretācijas joprojām iespējams apskatīt Facebook lapā 95 tēzes 95 dienās, kā arī LU TF tìmekḷa vietnē: https://www.tf.lu.lv/projekti.

Projekta darba grupa izsaka pateicību Universitātei par iespejju pieteikties projektu konkursiem un par finansējuma nodrošināšanu. Sirsnīgs paldies tiek izteikts arī LU TF paldies kolēǵiem un studentiem par iesaistîšanos un neviltoto morālo atbalstu. It īpaši vēlos izcelt vadošo pētnieci Ilzi Jansoni un studentu pašpārvaldes pārstāvi Bellu Brišku, kuras piedalījās projekta darba grupāa - vinu atbalsts bieži vien lika projektam virzīties uz priekšu. Paldies Kasparam Bankovskim par viņa darbu - tēžu tulkošanu - un par iespēju šo tulkojumu izmantot projektā. Paldies Laimonim Stikānam par projekta laikā izveidoto un nu jau "ikonisko" M. Lutera portreta vizualizējumu. Sirsn̄̄gs paldies visiem, kas piedalījās šajā projektā gan kā diskusiju dalībnieki un moderatori, gan arī kā tē̌̌u interpretatori. Bez jums šis projekts nevarētu izdoties, un bez jums arī nevarētu tapt šāda izstāde. Izstāde veidota, lai projekta rezultāti būtu uzskatāmāki un pārredzamāki, kā arī lai tie būtu pieejami plašākam sabiedrības lokam. Tā ir apskatāma LU TF gaitenī Rīgā, Raiņa bulvārī 19. 


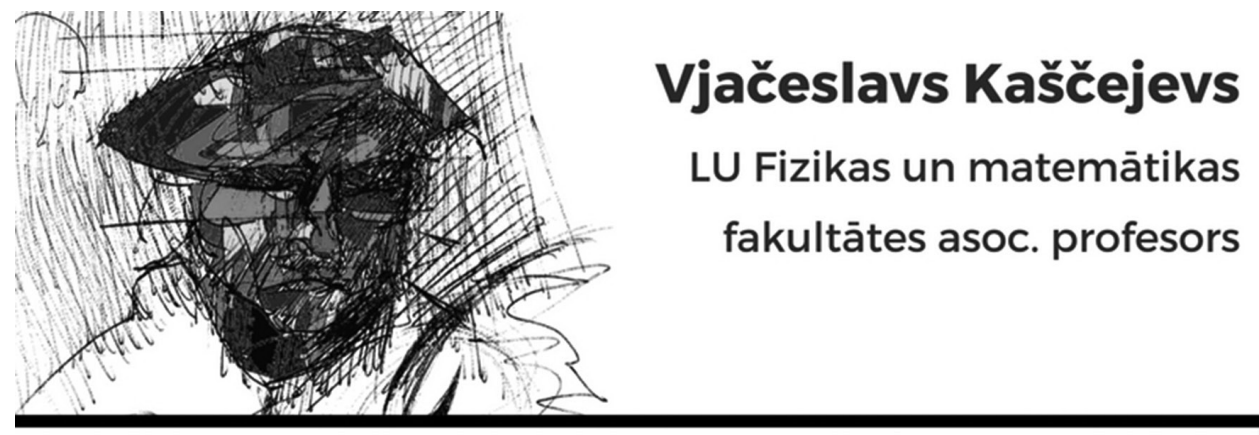

Viena no radītās pasaules lielajām mistērijām ir tās regularitāte, sekošana precīziem, matemātiski izsakāmajiem fizikas likumiem. 20. gadsimta teorētiskās fizikas dižgars Jūdžins Vīgners savā 1960. gada filozofiskas ievirzes rakstā to nosauca par "matemātikas neticamo rezultativitāti dabaszinātnēs" (The Unreasonable Effectiveness of Mathematics in the Natural Sciences). Es uztveru šo brīnumu kã nozīmìgu Radītāja žēlastības un cilvēka dievlīdzības izpausmi.

Kopš Lutera laika ir atklāti un sarakstīti biezi dabaszinātṇu kanoni. Katru gadu tiek iesvētīti tūkstošiem priesteru - zinātṇu doktoru. Daži seviški kaislīgi zinātnes pielūdzēji un scientisma apoloǵēti gaida no savām autoritātēm žēlastības pasludinājumu - tehnoloǵisko laimi, singularitāti vai bioloǵiskās apziṇas pārdzimšanu mākslīgā intelekta struktūrās.

Mārtiṇa Lutera 5. tēze atgādina katram laikmetam, cik svarīgi ir nesajaukt dieviškā atspulgu cilvēku prātos un autoritātēs ar pašu dieviško. Kopš Ėdenes notikumiem - Homo sapiens atmošanās - mūs nepamet kārdinājums vispārināt "es kaut ko zinu” uz "es zinu visu!"

Pāvests, priesteris vai zinātnieks var pārvaldīt un spriest tikai par to, kas tam atklāts un uzticēts. Šĩ vienkāršã patiesỉba nenoveco un palĩdz mums aiz paštaisnības nezaudēt Dieva žēlastību. 


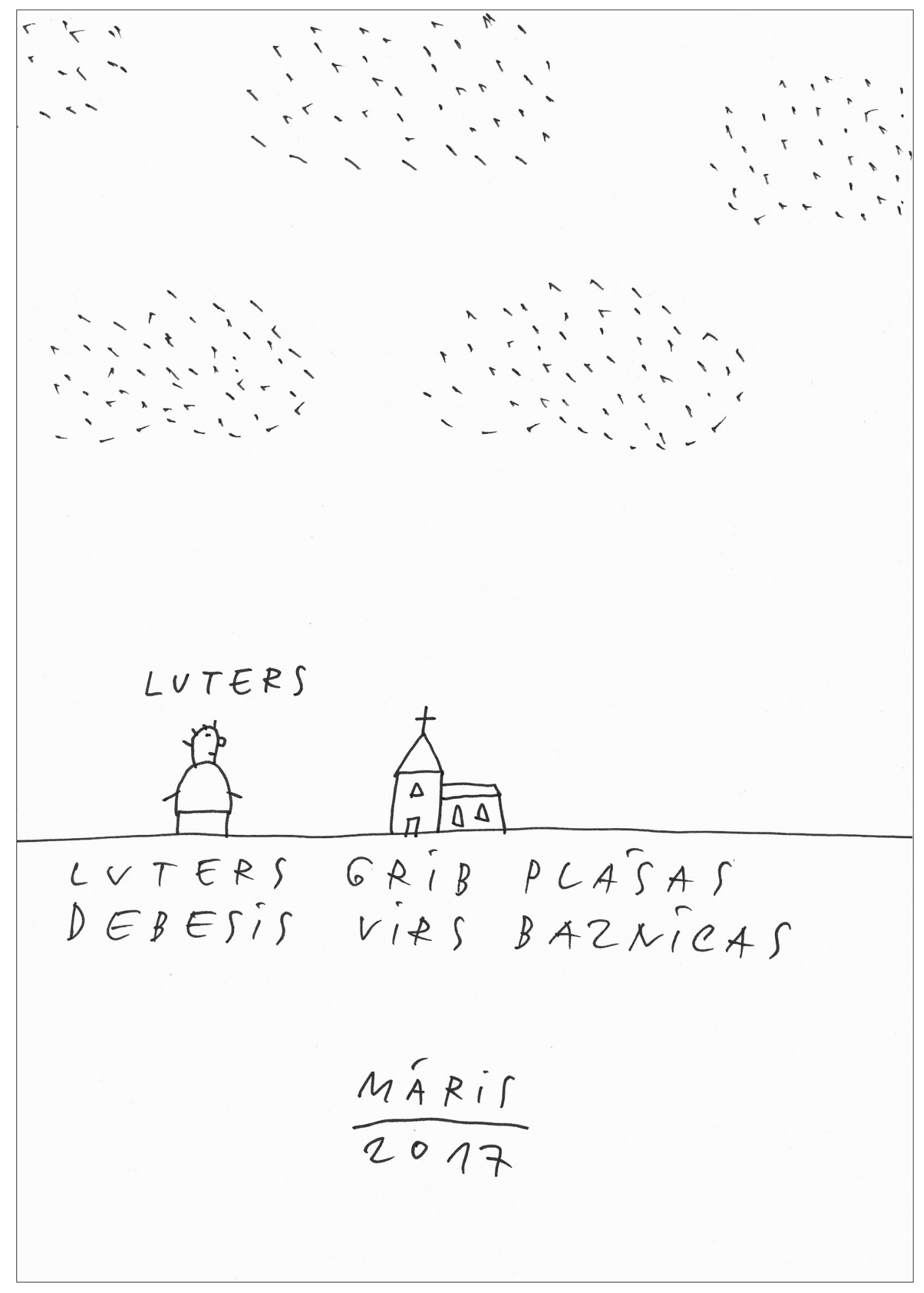

98

Akadēmiskā Dzīve 54/2018/2019 


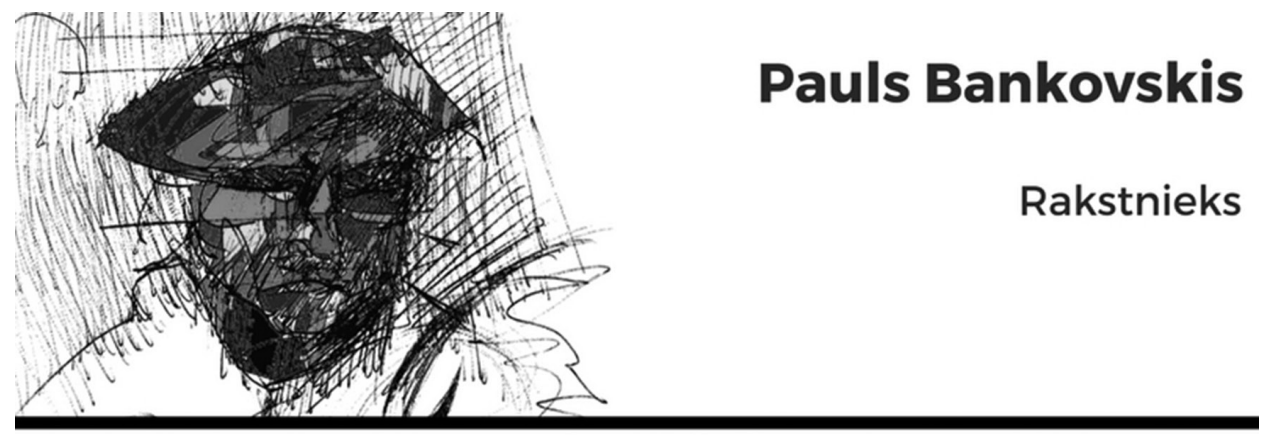

Par ko maksāt

Maksāšana par sen atmestām, jau sākotnēji nedzivām vai mirušām lietām laikam ir cilvēka dabā. Atbrīvošanās no savas sūri grūti nopelnìtās naudas nav nekas patīkams, tāpēc mēs mị̣u prātu ḷaujamies dažādiem apmāniem, kas tam ḷauj nepievērst pienācīgu uzmanību. Savukārt citu cilvēku dabā ir šādu pašapmānu manīgi izmantot savā labā. Jo, būsim godígi, pēc lìdziga principa darbojas gan dažādas tiešsaistes abonēšanas sistēmas ar automātisko abonementa atjaunošanu, gan tas, ko bezmaksas aplikāciju jeb lietotṇu izstrādātāji mēdz dēvēt par “iekšējiem pirkumiem". Atliek vienreiz vajadzigajos lauciņos iedot velnam mazo pirkstinu, tas ir kreditkartes un norēkinu informāciju, un skaties vien: drīz nebūs vairs arī visas rokas. Ja vien tāda jau nav izgudrota un pieejama tirgū, indulgenču tirgošanas aplikācija varētu būt îstens veiksmes stāsts arī mūsu dienās. To, protams, varētu iegūt par baltu velti, pilnīgi bez maksas, bet kaut kur ar tik tikko saburtojamiem sīciṇiem burtiṇiem būtu pierakstīts, ka šis programmas pilntiesīgas dárbības vārdā jums jāpiekrīt reizi mēnesī, nedẹ̄ā vai pat vēl biežăk škirties no nelielas naudas summas. lekasētā maksa būtu tik niecīga, ka neatstātu nekādas nozimigas pēdas jūsu dieniškajā budžetā. Nekādu lielu labumu jums nenestu ari pati aplikācija, taču viss noritētu tik êrti, pašsaprotami un neuzkrītoši,

ka tajos retajos brīžos, kad jūs par šiem saviem

pirkumiem aizdomātos, jūs savā ikdienas nevaḷā apṇemtos savā dzivē kaut labot ja ne rìt, tad noteikti parìt, bet tikmēr - lai viss pagaidām paliek, kā bijis. 